\title{
Cranial Osteology of the Armadillo Chaetophractus villosus (Mammalia, Xenarthra, Dasypodidae)
}

\author{
Osteología Craneana del Armadillo Chaetophractus villosus (Mammalia, Xenarthra, Dasypodidae) \\ "Squarcia, Silvia Margarita; *Sidorkewicj, Nora Silvia \& ** Casanave, Emma Beatriz
}

SQUARCIA, S. M.; SIDORKEWICJ, N. S. \& CASANAVE, E. B. Cranial osteology of the armadillo Chaetophractus villosus (Mammalia, Xenarthra, Dasypodidae). Int. J. Morphol., 24(4):541-547, 2006.

SUMMARY: The morphology and morphometry of the cranial bones of Chaetophractus villosus were studied. The skull components are morphologically similar between adults of both sexes, and follow the generalized pattern for most of described dasypodids. The morphometric analysis, however, demonstrated that the bones lying in the rostrocaudal plane are mostly longest in females, determining higher values of the total, basal and condilobasal lengths of the skull, which are the main variables that contribute to a sexual dimorphism in this species.

KEY WORDS: Dasypodidae; Morphology; Osteology; Skull; Sexual dimorphism.

\section{INTRODUCTION}

Chaetophractus villosus is a dasypodid commonly known as "larger hairy armadillo". It is distributed from the Chaco of Paraguay and Argentina; in Argentina to Tierra del Fuego (Deferrari et al., 2002); in Chile along the southeastern edge (Atalah, 1975; Wetzel, 1985).

The dasypodids constitute a significant xenarthran group owing to the place they have occupied in the mammalian phylogeny (Gaudin et al., 1996; Delsuc et al., 2003). Notwithstanding the essential of morphological evidence to phylogenetic studies, the knowledge about the skull of the extant dasypodids is incomplete. Some significant contributions on the cranial morphology of this group are available from Parker (1885), Patterson et al. (1989), Wible et al. (1990), Squarcia et al. (1993), Gaudin (1995). However, references about bone-by-bone description are very scarce (Wible \& Gaudin, 2004), and no antecedents are available for C. villosus.

The objectives of the present work are a) to perform morphological and morphometrical descriptions of the cranial bones of $C$. villosus; b) to elucidate if there are differences in the isolated bony components between adults of both sexes, taking into account the existence of a previous demonstrated sexual dimorphism in the whole skull of the species (Squarcia et al., 1999).

\section{MATERIAL AND METHOD}

Nineteen adults (10 females, 9 males) of Chaetophractus villosus were used; they were live-trapped in a ratio of approximately $80 \mathrm{Km}$ from the surroundings of Bahía Blanca city, Province of Buenos Aires, Argentina. The skulls were cleaned by conventional methods and exposed to consecutive treatments aimed to weaken the cranial sutures, those allowing us to isolate the bones: 1- boiling in $\mathrm{NaOH} 0.1 \mathrm{~N}$ (15 min); 2- immersion in ClH 0.1 N (5 min); 3- washed in current water.

For each bone, length (L) and width (W) or height $(\mathrm{H})$, were measured by means of a digital calliper to the nearest $0.01 \mathrm{~mm}$. The narial bones and the ethmoid-sphenoid complex were not measured owing to they suffered some damage during the separation instance. Mean values for the measured parameters were compared between sexes by using a two-tailed t-test (Sokal \& Rohlf, 1981).

* Cátedra de Anatomía Comparada, Universidad Nacional del Sur, Bahía Blanca, Argentina.

** Cátedra de Fisiología Animal, Departamento de Biología, Bioquímica y Farmacia, Universidad Nacional del Sur, Bahía Blanca, Argentina y Consejo Nacional de Investigaciones Científicas y Técnicas (CONICET), Argentina.

This study was funded by SGCyT (UNS), Project 24/B122, and by ANPCyT, BID 1728/OC PICTR 074/03. 
The existence of a mesethmoid in the species under study (see Ferigolo, 1981) was evaluated by examining the skulls of three litters: a 8-day-old male (M8), skull length (SL) $33 \mathrm{~mm}$; a 9-day-old female (F9), $35 \mathrm{~mm}$ SL; a 60-dayold female (F60), $58 \mathrm{~mm}$ SL.

\section{RESULTS AND DISCUSSION}

Morphology. Our results showed that the bony components of the adult skull of $C$. villosus are morphologically similar between sexes and follow the generalized pattern for most of described dasypodids (Grassé, 1955; Smith \& Redford, 1990; Wible \& Gaudin).

The paired nasal bones (Figs. 1a, b) are long and parallelogram-shaped, with rostral and caudal borders slanting and smooth. Their inner surfaces are slightly concave, passed over by a strong crest which contact with the nasoturbinal.

The right and left frontal bones (Figs. 1c, d) form together an arrowhead at the midline of the skull roof. Only rudiments of the postorbital process are present. The inner surface of each frontal has two fossae (rostral and caudal) separated by a single Y-shaped ridge.

Each parietal bone (Figs. 1e, f) resemble a parallelogram. An evident sagittal crest is not developed at the interparietal suture (Squarcia et al., 1993). Several small foramina corresponding to vascular openings are observed near the suture with the squamosal. The caudal edge is slanted and forms the rostral portion of a strong nuchal (=lambdoidal) crest. A longitudinal ridge run along the inner parietal face determining two rugose fossae.

The paired premaxillae (Fig. 1g) are shaped like hemicylinders. The palatal premaxillar process supports caudolaterally the first tooth and rostromedially an incisive foramen, as in the majority of the dasypodids (Grassé; Wible \& Gaudin).

The zygomatic process of the paired maxillae (Fig. $1 \mathrm{~h}, \mathrm{i}, \mathrm{j}$ ) is ventrally run through by the infraorbital canal, which is completely lateral to the maxillary body. The palatine process of both maxillary bones constitutes the $50 \%$ of the hard palate (Table I). Its outer border supports eight oval teeth, along the last three of which extends the maxillopalatine suture. The beginning of the zygomatic arch is placed between the fifth and sixth maxillary teeth.

The paired os nariale or septomaxillae (Fig. 1k) are small, thin and fragile J-shaped bones. These xenarthran bones have also been identified in many sauropsids and in certain mammals like monotremes (Novacek, 1993). The presence of a septomaxilla in xenarthrans constitutes probably a primitive character suggesting the retention of a sauropsid element lost in all other eutherians (Novacek), however from other approach, it could be a new element derived independently, constituting a neomorphic character (Wible et al., 1990). Within the Xenarthra, considerable variability has been documented about the presence of this element (Grassé). In dasypodids its presence would be linked to their fossorial habits, sharing in the protection of the naris during the burrowing (Casanave, 1989).

The paired lacrimal (Fig. 11) are relatively small wedge-shaped bones. They contribute to the rostral apophysis of the zygoma, as is characteristic in dasypodids (Frechkop \& Yepes, 1949; Grassé; Engelmann, 1985). The large lacrimal foramen is placed over the orbital edge, next to a small wrinkled tubercle.

The paired jugal (Fig. 1m) are long, laterally compressed bones, with a strong dorsal emargination in the anteromedial portion. The jugal-squamosal suture is horizontal and smooth. The postorbital process is rudimentary.

The horizontal processes of the paired palatine bones are nearly rectangular; the perpendicular processes are small and fragile (Fig. 1n).

The pterygoids (Fig. 10) are triangular and laminar bones. In the posterodorsal corner, a small process extends backwards to contact the tympanic bulla. The posteroventral corner projects a conspicuous hamular process (= hamulus). The contribution of the pterygoids to the hard palate is rather

Fig. 1. Skull components of Chaetophractus villosus. For the paired bones, the left component is showed. External views: a: nasal; c: frontal; e: parietal; g: premaxilla; h: maxilla; k: narial; 1: lacrimal; m: jugal; n: palatine; o: pterygoid; p: temporal; q: vomer; s: occipital; u: dentary. Internal views: b: nasal; d: frontal; f: parietal; i: maxilla; r: sphenoid; t: occipital; v: dentary. Abbreviations: anp: angular process of the dentary; as: alisphenoid; bo: basioccipital; bs: basisphenoid; cf: caudal fossa; conp: condylar process of the dentary; corp: coronoid process of the dentary; eam: external acoustic meatus; eth: ethmoid; fla: foramen lacerum anterius; fo: foramen ovale; ham: hamulus; hs: horizontal suture; ioc: infraorbital canal; lf: lacrimal foramen; mf: mandibular foramen; mp: mastoid process; mps: maxillopalatine suture; nc: nuchal crest; oc: occipital condyle; on: odontoid notch; ops: optic sulcus; os: orbitosphenoid; pgp: postglenoid process of the squamosal; popf: postorbital process of the frontal; popj: postorbital process of the jugal; rf: rostral fossa; so: supraoccipital; tb: tympanic bulla; zpm: zygomatic process of the maxilla; zpsq: zygomatic process of the squamosal. 


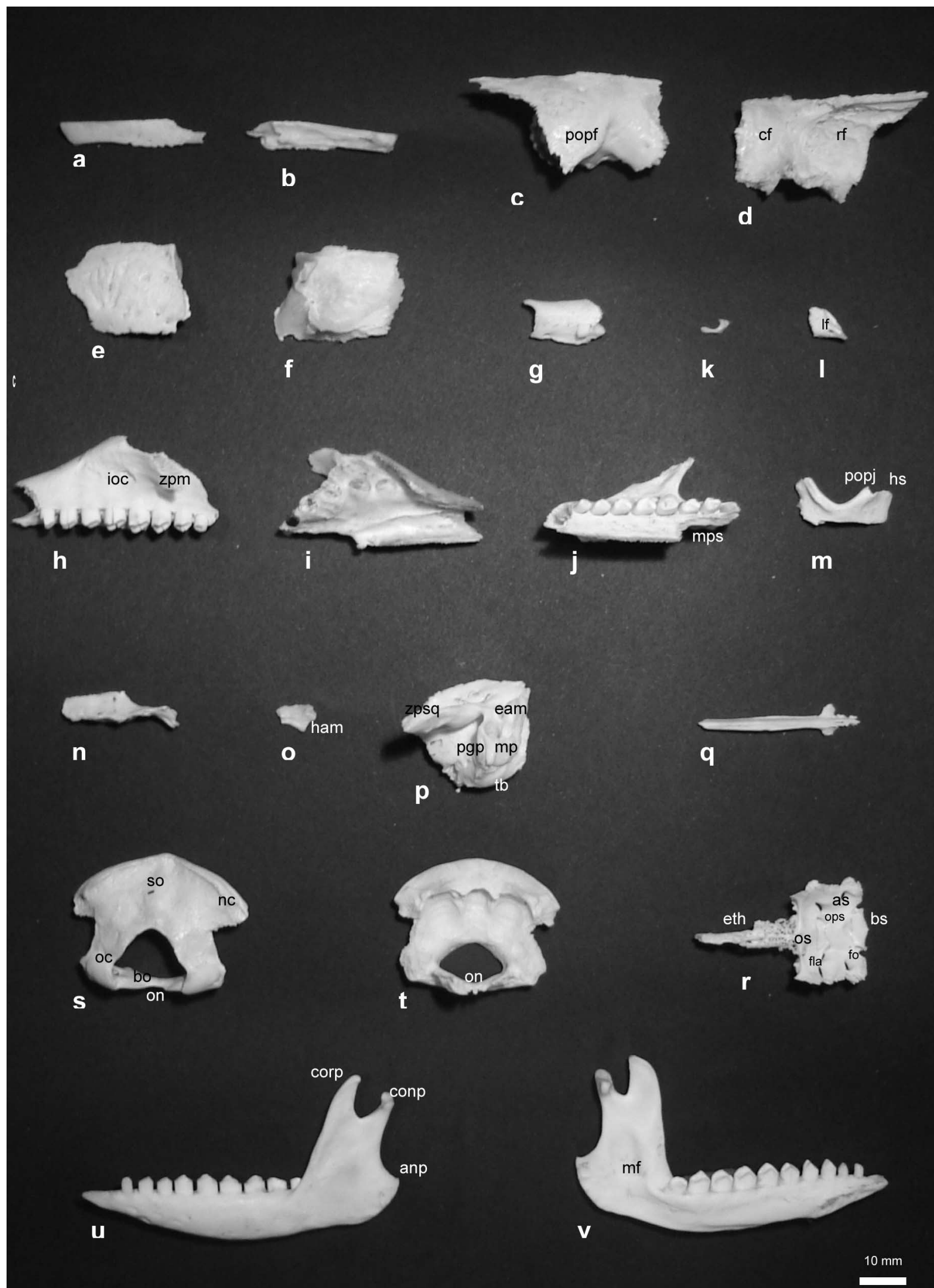



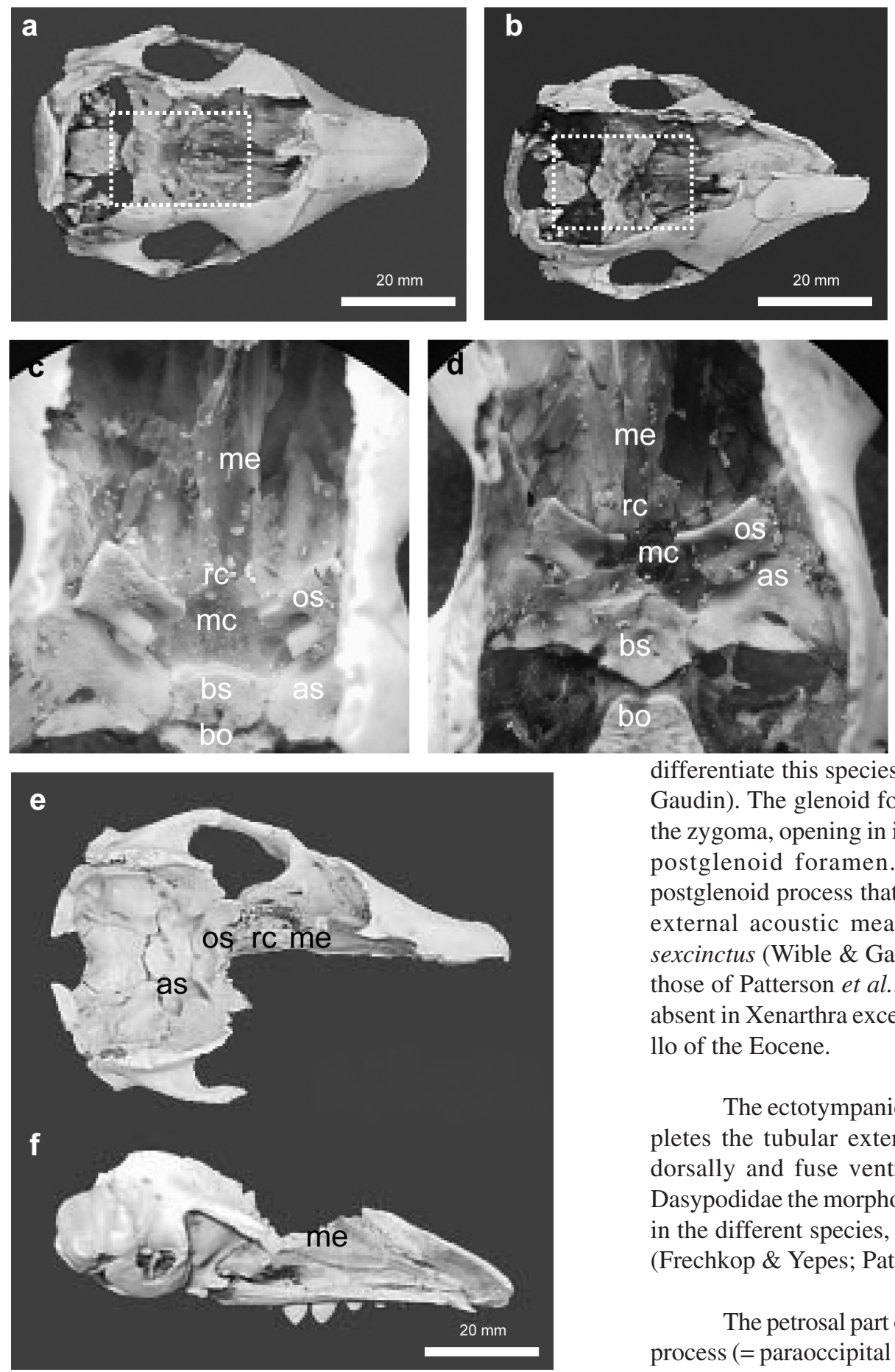

Fig. 2. Whole skull of the litters of Chaetophractus villosus, after partial removal of the braincase. Dorsal macroscopic views: a. Male 8-day-old (M8); b. Female 9-day-old (F9); e. Female 60-day-old (F60). Lateral macroscopic view: f(F60). Dorsal magnified views (10X): c (M8); d (F9). Abbreviations: mc: medial cartilage; me: mesethmoid; rc: rostral cartilage; the remainder as Fig. 1. variable within the xenarthrans. In $C$. villosus they are involved only in the lateral walls of the choanae, similarly to Euphractus sexcinctus (Smith \& Redford; Wible \& Gaudin), and contrarily to Dasypus where the pterygoids take part to some extent in the constitution of the hard palate (Grassé).

The squamosal portion of the paired temporal is valveshaped, fused caudoventrally to the petrosal part (Fig. 1p). The zygomatic apophysis of the squamosal is dorsoventrally compressed; then it rolls toward the distal end, becoming flattened in the latero-lateral direction. The height of the zygomatic apophysis at the level of the horizontal suture is lower than jugal's height, which differentiate this species of E. sexcinctus (Wetzel; Wible \& Gaudin). The glenoid fossa is deeply located at the base of the zygoma, opening in its posteriormost hidden part a large postglenoid foramen. There exists in this species a postglenoid process that forms the anterolateral face of the external acoustic meatus, as was reported also for $E$. sexcinctus (Wible \& Gaudin). These results are opposite to those of Patterson et al., who asserted that this character is absent in Xenarthra except for Utaetus buccatus, an armadillo of the Eocene.

The ectotympanic portion of the temporal bone completes the tubular external acoustic meatus, which open dorsally and fuse ventrally with the tympanic bulla. In Dasypodidae the morphology of the ectotympanic bone vary in the different species, which has a great taxonomic value (Frechkop \& Yepes; Patterson et al.).

The petrosal part of the temporal bone bears a mastoid process (= paraoccipital process for Wible \& Gaudin) which is flattened, short and wide.

The unpaired vomer (Fig. 1q) is a long and thin bone with two small caudal alae which projects sideways. Wible $\&$ Gaudin reported that the vomer in E. sexcinctus constitutes more than half the length of the skull; however for C. villosus it represents in average the $40 \%$ of the total cranial length (Table I). 
Table I. Traits measured for isolated cranial bones of Chaetophractus villosus (X: mean value; s.d.: standard deviation; C.V.: percent coefficient of variation; **: $\mathrm{p}<0.01 ; *$ : $<<0.05)$.

\begin{tabular}{|c|c|c|c|c|c|c|c|}
\hline & \multicolumn{2}{|c|}{ Total $(n=19)$} & \multicolumn{2}{|c|}{ Females $(n=10)$} & \multicolumn{2}{|c|}{ Males $(n=9)$} & \multirow[t]{2}{*}{$t$} \\
\hline & $X \pm$ s.d. & C.V. & $X \pm$ s.d. & C.V. & $X \pm s . d$ & C.V. & \\
\hline Nasal length & $34.3 \pm 1.4$ & 4.0 & $34.8 \pm 0.9$ & 2.5 & $33.7 \pm 1.7$ & 4.9 & 2.6 * \\
\hline Nasal width & $6.5 \pm 0.4$ & 6.6 & $6.5 \pm 0.4$ & 6.3 & $6.3 \pm 0.4$ & 6.2 & 2.1 * \\
\hline Frontal length & $40.7 \pm 2.4$ & 5.9 & $42.1 \pm 1.2$ & 2.8 & $38.8 \pm 2.2$ & 5.8 & $5.9 * *$ \\
\hline Frontal width & $22.2 \pm 1.0$ & 4.4 & $22.4 \pm 1.2$ & 5.3 & $22.0 \pm 0.6$ & 2.6 & 1.3 \\
\hline Parietal length & $26.6 \pm 1.0$ & 3.9 & $26.9 \pm 1.0$ & 3.7 & $26.3 \pm 1.0$ & 3.7 & 2.0 \\
\hline Parietal width & $19.0 \pm 0.7$ & 3.9 & $19.2 \pm 0.6$ & 3.3 & $18.7 \pm 0.8$ & 4.1 & 2.4 * \\
\hline Premaxillary length & $17.9 \pm 1.2$ & 6.5 & $18.4 \pm 1.0$ & 5.2 & $17.3 \pm 1.1$ & 6.6 & $3.1^{* *}$ \\
\hline Premaxillary width & $7.0 \pm 0.6$ & 8.9 & $7.3 \pm 0.6$ & 7.7 & $6.6 \pm 0.4$ & 6.6 & $4.3^{* *}$ \\
\hline Maxillary length & $43.6 \pm 2.8$ & 6.3 & $45.0 \pm 1.8$ & 4.1 & $41.8 \pm 2.7$ & 6.6 & $4.3^{* *}$ \\
\hline Maxillary width & $12.0 \pm 0.8$ & 6.5 & $12.3 \pm 0.7$ & 5.4 & $11.7 \pm 0.8$ & 7.2 & 2.2 * \\
\hline Lacrimal length & $11.3 \pm 1.2$ & 11.1 & $11.3 \pm 1.2$ & 11.1 & $10.2 \pm 0.9$ & 9.3 & $7.9^{* *}$ \\
\hline Lacrimal height & $6.7 \pm 0.6$ & 8.8 & $6.7 \pm 0.6$ & 8.8 & $6.2 \pm 0.5$ & 8.2 & 5.9 ** \\
\hline Jugal length & $24.7 \pm 1.0$ & 4.1 & $24.7 \pm 1.0$ & 4.1 & $24.2 \pm 1.1$ & 4.5 & 3.0 ** \\
\hline Jugal height & $8.2 \pm 0.7$ & 8.2 & $8.2 \pm 0.7$ & 8.2 & $8.2 \pm 0.6$ & 7.8 & -0.0 \\
\hline Palatine length & $21.6 \pm 1.2$ & 5.6 & $22.1 \pm 1.1$ & 5.2 & $20.8 \pm 0.8$ & 4.1 & $3.7^{* *}$ \\
\hline Palatine width & $7.6 \pm 0.4$ & 5.2 & $7.6 \pm 0.4$ & 5.8 & $7.6 \pm 0.3$ & 4.4 & 0.6 \\
\hline Pterygoid length & $9.2 \pm 0.4$ & 4.4 & $9.3 \pm 0.3$ & 3.9 & $9.1 \pm 0.4$ & 4.9 & 1.5 \\
\hline Pterygoid height & $5.6 \pm 0.4$ & 7.2 & $5.8 \pm 0.3$ & 5.7 & $5.3 \pm 0.4$ & 6.7 & $3.8^{* *}$ \\
\hline Temporal length & $25.3 \pm 0.7$ & 2.7 & $25.6 \pm 0.6$ & 2.3 & $24.9 \pm 0.6$ & 2.6 & $3.2^{* *}$ \\
\hline Temporal height & $23.8 \pm 0.7$ & 2.9 & $23.8 \pm 0.7$ & 3.0 & $23.8 \pm 0.7$ & 2.8 & 0.0 \\
\hline Vomer length & $36.6 \pm 2.0$ & 5.5 & $37.7 \pm 1.6$ & 4.1 & $35.2 \pm 1.7$ & 4.8 & $4.5^{* *}$ \\
\hline Vomer width & $6.7 \pm 0.6$ & 9.4 & $7.0 \pm 0.5$ & 7.4 & $6.3 \pm 0.5$ & 8.7 & 4.0 ** \\
\hline Occipital length & $16.9 \pm 0.5$ & 3.0 & $16.9 \pm 0.6$ & 3.6 & $17.0 \pm 0.4$ & 2.2 & -0.2 \\
\hline Occipital width & $37.3 \pm 1.3$ & 3.6 & $37.9 \pm 1.1$ & 2.9 & $36.5 \pm 1.2$ & 3.3 & 3.6 ** \\
\hline Dentary length & $71.5 \pm 1.9$ & 3.0 & $72.5 \pm 2.0$ & 2.7 & $70.1 \pm 1.3$ & 2.2 & $6.3^{* *}$ \\
\hline Dentary height & $39.2 \pm 1.9$ & 5.1 & $40.2 \pm 1.9$ & 5.2 & $38.6 \pm 1.8$ & 4.2 & $3.8^{* *}$ \\
\hline
\end{tabular}


At the ethmoidal region, an independent ossification which we consider that corresponds to the mesethmoid was observed in the skull of the three litters examined (Fig. 2). In the youngest specimens, this element $(3.28 \mathrm{~mm}$ length in M8; 3.40 mm length in F9) is isolated from two caudal orbitosphenoid ossifications by a rostral cartilaginous tissue. A broad medial cartilage $(2.76 \mathrm{~mm}$ width in M8; $2.59 \mathrm{~mm}$ width in F9) isolate also the right from the left orbitosphenoid bones. In the remaining specimen (F60) the mesethmoid ossification is $9.33 \mathrm{~mm}$ long; the orbitosphenoid elements are now fused and isolated from the mesethmoid also by a rostral cartilaginous tissue. In the skulls of none of the adults examined this ossification was evident as an independent element, so it could be fused to the bones of the cranial base. The earliest description of an independent mesethmoid in the dasypodids come from Ferigolo who observed this element in juveniles of $E$. sexcinctus. Thus, from these findings it is priority to revue the Broom's concept (Broom, 1926) who classified the xenarthrans into the Superorder Palaeotherida owing to the absence of a mesethmoid. However, further studies are needed in order to elucidate if all dasypodids are to be classified as Neotherida or if this is a rare condition limited to only some species of the group.

In the skulls of the litters examined no separate center of ossification corresponding to the presphenoid was observed, and the orbitosphenoids fuse in the midline similarly to that reported in other species of dasypodids (Ferigolo). The paired orbitosphenoid supports a well developed optic sulcus, which open externally by the optic foramen close to the foramen lacerum anterius (= sphenorbital fissure). The latter is placed in the junction of orbitosphenoid and alisphenoid, whereas the foramen ovale is entirely in the alisphenoid (Fig. 1r). Contrarily to us, Novaceck \& Wyss (1986) reported that in edentates the foramen ovale is placed between the alisphenoid and periotic. The presence of a foramen ovale included entirely in the alisphenoid was considered as a primitive condition within the xenarthrans (Gaudin et al.), which constitutes a topic of interest for the analysis of morphological evidence in order to elucidate the mammalian phylogeny. Another point of disagreement refers to the terminology, presence and location of the foramen rotundum within the xenarthrans (McDowell, 1958; Wible \& Gaudin). We have observed that in C. villosus this foramen is lacking, similarly to E. sexcinctus and Dasypus kappleri (Wible \& Gaudin).

The occipital complex (Figs. 1s, t) is fused to the basisphenoid. The unpaired basioccipital portion is roughly trapezoidal, with two conspicuous ovoid muscular fossae. The odontoid notch is V-shaped with the vertex rounded. The supraoccipital portion is approximately pentagonal, with lateral emarginated borders and a remarkable V-shaped nuchal crest along the occipitoparietal suture. Its outer face has three convexities that correspond with inner concavities isolated by two strong ridges. The small paired exoccipital portion supports the cylindrical condyles at whose base open condylar foramina.

Each dentary (Figs. 1u, v) is a solid element, with a narrow horizontal tooth-bearing body and a broad vertical ramus. The body supports ten oval teeth, whose rostrocaudal diameter is maximum at sixth and seventh alveoli. The three processes of the ramus lye dorsal to the alveolar level. Like in E. sexcinctus, the coronoid process is longer than the condyle and "somewhat shark fin-shaped, with the fin pointing posteriorly" (Wible \& Gaudin). The articular surface of the condylar process is transversely rectangular and gently concave. The angular process is sharp and rugose. The foramen mandibulae is located in a conspicuous large ovoid depression of the inner face.

Morphometry. Notwithstanding the absence of differences in the morphological features of the cranial bony components of $C$. villosus between sexes, the morphometric analysis demonstrated that most bones lying in the rostrocaudal plane are longer in females than in males (Table I). These components contribute to overall determine the total, basal and condilobasal lengths of the skull, which have demonstrated to be the main variables that indicate a clear-cut sexual dimorphism in this species (Squarcia et al., 1993, 1999).

SQUARCIA, S. M.; SIDORKEWICJ, N. S. \& CASANAVE, E. B. Osteología craneana del armadillo Chaetophractus villosus (Mammalia, Xenarthra, Dasypodidae). Int. J. Morphol., 24(4):541-547, 2006.

RESUMEN: Realizamos estudios morfológico y morfométrico de los componentes óseos del cráneo de Chaetophractus villosus. Los huesos son morfológicamente semejantes en ambos sexos y siguen el patrón generalizado de la mayoría de los dasipódidos descritos. El análisis morfométrico, sin embargo, demostró que la mayoría de los huesos ubicados en el plano rostrocaudal son más largos en las hembras, determinando mayores valores de longitudes total, basal y cóndilobasal del cráneo, que son las principales variables que contribuyen a determinar el dimorfismo sexual en esta especie.

PALABRAS CLAVE: Dasypodidae; Morfología; Osteología; Cráneo; Dimorfismo sexual. 


\section{REFERENCES}

Atalah, G. A. Presencia de Chaetophractus villosus (Edentata, Dasypodidae) nueva especie para la región de Magallanes, Chile. Anal. Inst. Patagonia, Punta Arenas (Chile), 6 (12):169-71, 1975.

Broom, R. On the mammalian presphenoid and mesethmoid bones. Proc. Zool. Soc. London, 257-64, 1926.

Casanave, E. B. Estudio sobre las reacciones fisiológicas de Chaetophractus villosus sometido a enterramiento experimental. Tesis Doctoral. Facultad de Ciencias Exactas y Naturales, Universidad de Buenos Aires, 2 vol., 238 pp., 1989.

Deferrari, G.; Camilion, C.; Escobar, J. \& Lizarralde, M. S. Presencia de Chaetophractus villosus en Tierra del Fuego: Nueva especie introducida. ¿Nuevo problema?. Resúmenes XVII Jornadas Argentinas de Mastozoología, Mar del Plata: 24, 2002.

Delsuc, F. ; Stanhope, M. J. \& Douzery, E. J. P. Molecular systematics of armadillos (Xenarthra, Dasypodidae) : contribution of maximum likelihood and Bayesian analysis of mitochondrial and nuclear genes. Mol. Phylogenet. Evol., 28: 261-75, 2003.

Engelmann, G. F. The phylogeny of the Xenarthra. In: Montgomery, G. G. (ed.). The evolution and ecology of Armadillos, Sloths and Vermilingues. Smithsonian Institution Press, Washington, D. C., 1985. pp. 51-64.

Ferigolo, J. The mesethmoid bone and the Edentata. An. Acad. Bras. Cienc. Río de Janeiro, 53 (4):817-24, 1981.

Frechkop, S. \& Yepes, J. Étude systematique et zoogéographique des Dasypodidés conservés a l'Institut. Bull. Inst. Roy. Sc. Nat., Bruxelles, 25(5):1-56, 1949.

Gaudin, T. J. The ear region of edentates and the phylogeny of the Tardigrada (Mammalia: Xenarthra). J. Vertebr. Paleontol., 15:672-705, 1995.

Gaudin, T. J.; Wible, J. R.; Hopson, J. A. \& Turnbull, W. D. Reexamination of the morphological evidence for the cohort Epitheria (Mammalia, Eutheria). J. Mammal. Evol., 3: 3179, 1996.

Grassé, P. P. Ordre des Edentés. In: Grassé, P. (ed), Traité de Zoologie. Paris, Masson, pp. 1182-266, 1955. V. 17. Fasc. II.

McDowell, S. B. Jr. The Greater Antillean insectivores. Bull. Amer. Mus. Nat. Hist., 115:113-214, 1958.
Novacek, M. J. Patterns of Diversity in the Mammalian Skull. In: Hanken, J. \& Hall, B. K. (eds.). The Skull. University of Chicago Press, Chicago, pp. 438-545, 1993. V. 2.

Parker, W. K. On the development of the skull in the Mammalia. Part II: Edentata. Phil. Trans. Roy. Soc. London, 37:1-119, 1885.

Patterson, B.; Segall, W. \& Turnbull, W. D. The ear region in xenarthrans (= Edentata: Mammalia) Part I. Xingulates. Fieldiana, Geology, New Series, 18:1-46, 1989.

Smith, K. K. \& Redford, K. H. The anatomy and function of the feeding apparatus in two armadillos (Dasypoda): anatomy is not destiny. J. Zool., Lond., 222:27-47, 1990.

Sokal, R. R. \& Rohlf, F. J. Biometry, $2^{\text {nd }}$. Ed. W. H. Freeman and Co., New York, 1981.

Squarcia, S. M.; Casanave, E. B. \& Cirone, G. R. Morfología craneana de Chaetophractus villosus (Mammalia, Dasypodidae). Iheringia, Série Zool., Porto Alegre, 75:556, 1993.

Squarcia, S. M.; Casanave, E. B. \& Cirone, G. R. Sexual dimorphism in Chaetophractus villosus (Mammalia, Dasypodidae) based on craniometrical characters. An. Mus. Hist. Nat. Valparaíso, 24:91-4, 1999.

Wetzel, R. M. Taxonomy and Distribution of Armadillos, Dasypodidae. In: Montgomery, G. G. (ed.). The evolution and ecology of Armadillos, Sloths and Vermilingues. Smithsonian Institution Press, Washington, D. C., pp. $23-$ 46, 1985.

Wible, J. R. \& Gaudin, T. J. On the cranial osteology of the yellow armadillo Euphractus sexcinctus (Dasypodidae, Xenarthra, Placentalia). An. Carn. Mus., 73 (3):117-96, 2004.

Wible, J. R.; Miao, D. \& Hopson, J. A. The septomaxilla in fossil and recent synapsids and the problem of the septomaxilla of monotremes and armadillos. Zool. J. Linn. Soc., 98:203-28, 1990.

Correspondence to:

Prof. Dra. Silvia Margarita Squarcia

Received: 09-06-2006

Cátedra de Anatomía Comparada

Accepted: 12-09-2006

Universidad Nacional del Sur (UNNS)

8000. Bafía Blanca

ARGE $\mathcal{N}$ TINA

E-mail: squarcia@criba.edu.ar; casanave@criba.edu.ar. 
